\title{
ACID-BASE REGULATION, METABOLISM AND ENERGETICS IN SIPUNCULUS NUDUS AS A FUNCTION OF AMBIENT CARBON DIOXIDE LEVEL
}

\author{
H. O. PÖRTNER ${ }^{1,3, *}$, A. REIPSCHLÄGER ${ }^{1, \dagger}$ AND N. HEISLER ${ }^{2,3}$ \\ ${ }^{1}$ Alfred-Wegener-Institut für Polar- und Meeresforschung, Biologie I/Ökophysiologie, D-27515 Bremerhaven, \\ Germany, ${ }^{2}$ Lehrstuhl für Tierphysiologie, Humboldt Universität zu Berlin, D-10115 Berlin, Germany and \\ ${ }^{3}$ Max-Planck-Institut für experimentelle Medizin, Göttingen, Germany \\ *e-mail: hpoertner@awi-bremerhaven.de \\ $\dagger$ Present address: Institut für Tierphysiologie, Freie Universität Berlin, Grunewaldstrasse 34, D-12165, Berlin, Germany
}

Accepted 9 October 1997; published on WWW 9 December 1997

\begin{abstract}
Summary
Changes in the rates of oxygen consumption and ammonium excretion, in intra- and extracellular acid-base status and in the rate of $\mathrm{H}^{+}$-equivalent ion transfer between animals and ambient water were measured during environmental hypercapnia in the peanut worm Sipunculus nudus. During exposure to $1 \% \mathrm{CO}_{2}$ in air, intracellular and coelomic plasma $P_{\mathrm{CO}_{2}}$ values rose to levels above those expected from the increase in ambient $\mathrm{CO}_{2}$ tension. Simultaneously, coelomic plasma $\mathrm{PO}_{2}$ was reduced below control values. The rise in $\boldsymbol{P}_{\mathrm{CO}_{2}}$ also induced a fall in intraand extracellular $\mathrm{pH}$, but intracellular $\mathrm{pH}$ was rapidly and completely restored. This was achieved during the early period of hypercapnia at the expense of a non-respiratory increase in the extracellular acidosis. The $\mathrm{pH}$ of the extracellular space was only partially compensated (by $37 \%$ ) during long-term hypercapnia. The net release of basic equivalents under control conditions turned to a net release of protons to the ambient water before a net, albeit reduced, rate of base release was re-established after a new steady state had been achieved with respect to acid-base parameters.

the level of Gibbs free energy change of ATP hydrolysis, before replenishment of phosphagen and restoration of $\mathrm{pHi}$ and energy status occurred in parallel.

In conclusion, long-term hypercapnia in vivo causes metabolic depression, a parallel shift in acid-base status and increased gas partial pressure gradients, which are related to a reduction in ventilatory activity. The steadystate rise in $\mathrm{H}^{+}$-equivalent ion transfer to the environment reflects an increased rate of production of protons by metabolism. This observation and the reduction of the $\mathrm{O} / \mathrm{N}$ ratio suggest that a shift to protein/amino acid catabolism has taken place. Metabolic depression prevails, with completely compensated intracellular acidosis during longterm hypercapnia eliminating intracellular $\mathrm{pH}$ as a significant factor in the regulation of metabolic rate in vivo. Fluctuating levels of the phosphagen, of free ADP and in the ATP free energy change values independent of $\mathrm{pH}$ are interpreted as being correlated with oscillating ATP turnover rates during early hypercapnia and as reflecting a tight coupling of ATP turnover and energy status via the level of free ADP.
\end{abstract}

Hypercapnia also affected the mode and rate of metabolism. It caused the rate of oxygen consumption to fall, whereas the rate of ammonium excretion remained constant or even increased, reflecting a reduction of the $\mathrm{O} / \mathrm{N}$ ratio in both cases. The transient intracellular acidosis preceded a depletion of the phosphagen phospho-Larginine, an accumulation of free ADP and a decrease in
Key words: acid-base regulation, ammonia excretion, buffer value, $\mathrm{CO}_{2}$ partial pressure, environmental hypercapnia, extracellular $\mathrm{pH}$, free ADP, Gibb's free energy change of ATP hydrolysis, $\mathrm{H}^{+}$transfer, intracellular $\mathrm{pH}$, metabolic depression, nitrogen metabolism, phospho-L-arginine, ventilation, peanut worm, Sipunculus nudus.

\section{Introduction}

The sipunculid worm Sipunculus nudus is exposed to low tide for periods of different duration in its natural environment, the intertidal zone. During low tides, the infauna and epifauna experience hypoxia as well as an increase in $\mathrm{CO}_{2}$ partial pressures (hypercapnia) as a result of reduced gas exchange caused by the restricted access to surface water. It is well established that intertidal animals are able to tolerate extended periods of hypoxia by decreasing their metabolic rate. Extreme hypoxia in Sipunculus nudus causes energy expenditure to fall by $50-70 \%$ (Hardewig et al. 1991). Metabolic depression also affects the acid-base status and leads to a reduced rate of $\mathrm{H}^{+}-$ equivalent ion exchange (Pörtner et al. 1991) associated with shifted set points of acid-base regulation. During anoxic exposure, intracellular $\mathrm{pH}$ is regulated at a value approximately 0.3 units below that maintained under normoxia (Pörtner, 1993). 
The potential contribution of $\mathrm{CO}_{2}$ to metabolic depression in intertidal animals has not been investigated, and the effects of $\mathrm{CO}_{2}$ on the mechanisms of acid-base regulation in these animals are insufficiently understood. Lindinger et al. (1984) reported that hypercapnia causes a respiratory acidosis in the extracellular fluid (haemolymph) and a mixed respiratory and non-respiratory acidosis in the intracellular space of the bivalve Mytilus edulis. Both intra- and extracellular acidification were only partially compensated in this species. A number of studies conducted on brine shrimp Artemia embryos and land snails have shown that, during hypercapnia in whole animals, $\mathrm{CO}_{2}$ elicits a depression of metabolic rate (Busa and Crowe, 1983; Barnhart and McMahon, 1988; Hand and Gnaiger, 1988; Barnhart, 1989; Rees and Hand, 1990). In contrast, Silver and Jackson (1985) and Jackson et al. (1988) reported that experimentally elevated $\mathrm{CO}_{2}$ levels had no influence on the metabolic rate of freshwater turtles Chrysemys picta bellii. For brine shrimp embryos, the depressant effect of $\mathrm{CO}_{2}$ on metabolism is interpreted to be largely via acidotic changes in intracellular pH (Busa and Crowe, 1983; Hand and Gnaiger, 1988). Such a role of $\mathrm{pHi}$ in the downregulation of metabolic rate, however, has been questioned for other organisms (Brooks and Storey, 1989; Rees and Hand, 1991; Scholnick et al. 1994), among them Sipunculus nudus (Reipschläger and Pörtner, 1996).

Parallel work on $S$. nudus has been carried out in isolated muscle preparations (Reipschläger and Pörtner, 1996). The aim of the present study was to delineate the time course of the effects of hypercapnia on acid-base status, to quantify the responses of the acid-base regulatory system and to analyse changes in oxygen consumption, ammonia excretion and energy status associated with elevated ambient $\mathrm{CO}_{2}$ tensions in Sipunculus nudus in vivo. Focusing on the specific effects of gaseous $\mathrm{CO}_{2}$, analyses were always performed under conditions of sufficient access to oxygen for the animals. Intraand extracellular $\mathrm{pH}, \mathrm{P}_{\mathrm{CO}_{2}}$ and bicarbonate levels were determined and utilized, together with tissue buffer values estimated under well-defined metabolic control conditions, in a quantitative treatment of the overall acid-base balance. To evaluate the specific effects of $\mathrm{CO}_{2}$, the importance of changing bicarbonate levels in the water at constant $P_{\mathrm{CO}_{2}}$ was also investigated during the analyses of the whole-animal acid-base status.

\section{Materials and methods \\ Experimental animals}

Specimens of Sipunculus nudus L. (26-74 g) were collected by digging them up from intertidal flats at Locquémeau, Brittany, France, in September and April. The animals were kept in tanks with a $10-20 \mathrm{~cm}$ layer of sand from the original habitat for at least 1 week prior to experimentation. The holding tanks were supplied with filtered and recirculated artificial sea water at $10-15^{\circ} \mathrm{C}$. Water bicarbonate level was adjusted to a constant level of approximately $2.3 \mathrm{mmoll}^{-1}$ by titration with $\mathrm{HCl}$.

\section{Experimental procedure}

Prior to experimentation, the animals were catheterized by introducing a $2-3 \mathrm{~cm}$ length of PE 60 or PE 90 tubing (total length $75 \mathrm{~cm}$ ) into the coelomic cavity after puncturing the posterior end of the body. The tubing was secured with cyanoacrylate glue. The long-term viability of the cannulated specimens and the stability of steady-state control acid-base parameters had been established previously (Pörtner et al., 1991). After $24 \mathrm{~h}$ of acclimation to the experimental conditions under normoxic normocapnia $\left(P_{\mathrm{O}_{2}} \approx 100 \mathrm{mmHg}\right.$ or $13.3 \mathrm{kPa}$, $P_{\mathrm{CO}_{2}} \approx 0.6 \mathrm{mmHg}$ or $0.08 \mathrm{kPa}$ ), the animals were exposed to environmental hypercapnia $\left(1 \% \mathrm{CO}_{2}\right)$ by equilibration of the water with gas mixtures prepared from pure $\mathrm{N}_{2}, \mathrm{O}_{2}$ and $\mathrm{CO}_{2}$ using precision gas-mixing pumps (Wösthoff, Bochum, Germany, type $\mathrm{M} 303 / \mathrm{a}-\mathrm{F}) .1 \% \mathrm{CO}_{2}$ was chosen as a high $\mathrm{CO}_{2}$ level experienced by the animals in their natural environments. During experimentation in normocapnic sea water, animals were exposed to different water levels of water bicarbonate, originating from titration with hydrochloric acid or solid sodium bicarbonate (see below). The incubation water was exchanged with fresh sea water at intervals of $24 \mathrm{~h}$.

$\mathrm{H}^{+}$-equivalent ion transfer processes, contributing to acid-base regulation of the whole animal, were quantified in the closed, darkened seawater recirculation system described by Pörtner et al. (1991). In brief, the system contained between 300 and $470 \mathrm{ml}$ of artificial sea water thermostatted to $15 \pm 0.05^{\circ} \mathrm{C}$. Animal chambers (selected to match the size of the animals) were connected to a gas-exchange column. Gases fed into the column were thermostatted to $15^{\circ} \mathrm{C}$ and humidified to minimize evaporative water loss. The water was recirculated at a rate of $100 \mathrm{ml} \mathrm{min}^{-1}$ using a roller pump (type MP-GE, Ismatec, Zürich, Switzerland). In accordance with the direction of water flow in the natural burrow, water passed along the body surface from the anterior to the posterior end of the animal. After placing the animal in the chamber, the cannula was fed through the aeration column. During the acclimation period, water $P_{\mathrm{O}_{2}}$ values ranged between 100 and $120 \mathrm{mmHg}(13.3-16 \mathrm{kPa})$ and $P_{\mathrm{CO}_{2}}$ between 0.4 and $0.7 \mathrm{mmHg}(0.05-0.09 \mathrm{kPa})$. The initial seawater bicarbonate level was adjusted to $2.3 \mathrm{mmoll}^{-1}$, but was allowed to rise to $3 \mathrm{mmoll}^{-1}$ during the experiment as a result of the release of bicarbonate by the animal. After $24-48 \mathrm{~h}$ of control incubation, the gas supply was switched to $1 \% \mathrm{CO}_{2}$ in air and the incubation was continued for 6-7 days. After this period, the experiment was terminated or continued with an additional normocapnic control period of up to 4 days (see Fig. 5).

Water from the aeration column was recirculated continuously at a rate of $6.6 \mathrm{ml} \mathrm{min}{ }^{-1}$ by means of a second roller pump (Ismatec IP 4, Zürich), feeding a ' $\Delta$-bicarbonate system' (Heisler, 1989) to monitor changes in water $\mathrm{pH}$ and, thus, bicarbonate levels. Bicarbonate level was calculated from $P_{\mathrm{CO}_{2}}$ and $\mathrm{pH}$ according to Heisler $(1984,1989)$. During passage through the system, the water was thermostatted to $30 \pm 0.05^{\circ} \mathrm{C}$ and equilibrated with humidified gas at constant $1 \% \mathrm{CO}_{2} . \mathrm{pH}$ was measured by means of a glass electrode and a double-electrolyte bridge $\mathrm{Ag} / \mathrm{AgCl}$ reference with a sleeve 
diaphragm connected to a high-impedance isolation amplifier (model 87, Knick, Berlin, Germany). The signal was recorded on a chart recorder and fed, after A/D conversion, into a microcomputer system for on-line analysis. The accuracy of the calculation was checked by the addition of known amounts of $\mathrm{HCl}$ and $\mathrm{NaHCO}_{3}$ to the system and by analysis of the total $\mathrm{CO}_{2}$ in the water sampled from the $\Delta$-bicarbonate system.

Intracellular acid-base parameters were determined in animals incubated in darkened aquaria containing 51 of artificial sea water. After exposure to $1 \% \mathrm{CO}_{2}$ under normoxic conditions for various times, coelomic fluid samples were withdrawn and analysed as described below. Animals were dissected as quickly as possible, and the body wall musculature was freeze-clamped by means of a Wollenberger clamp precooled in liquid nitrogen. Muscle samples were wrapped in aluminium foil and stored under liquid nitrogen until analysed.

Rates of oxygen consumption and ammonia excretion were studied by closed-system respirometry at $15^{\circ} \mathrm{C}$. Changes in water oxygen partial pressure were monitored for $2-3 \mathrm{~h}$ using a Clarke-type electrode (Eschweiler, Kiel, Germany). Water samples were taken from the respiration chamber at the beginning and at the end of this period and were analysed for ammonia as described below.

To obtain recordings with an acceptable signal-to-noise ratio, ventilatory frequency was monitored in cannulated animals dwelling in a $10 \mathrm{~cm}$ bottom layer of sand in darkened aquaria containing 151 of aerated natural sea water at $15^{\circ} \mathrm{C}$. Each animal was connected to a pressure transducer (UFI, type 1050, Morro Bay, CA, USA) via the indwelling catheter. The ventilatory activity was monitored as the frequency of coelomic fluid pressure fluctuations (see Zielinski and Pörtner, 1996) by using a MacLab system (ADI Instruments, Hastings, UK) under control conditions, during long-term hypercapnia and during subsequent recovery and taking into account the protocol of oxygen consumption measurements. Moreover, some animals were maintained under normocapnia and infused with $10 \mu \mathrm{g} \mathrm{g}^{-1}$ body mass of saline containing $1.5 \mathrm{mmol}^{-1}$ adenosine following the rationale of Reipschläger et al. (1997).

\section{Analyses}

Coelomic fluid samples were collected repeatedly from the animals (approximately $0.7 \mathrm{ml}$ from a total volume of $13.5-18 \mathrm{ml}$ ) in the $\Delta$-bicarbonate system. Samples were analyzed for extracellular $\mathrm{pH}, \mathrm{PCO}_{2}$ and $\mathrm{P}_{\mathrm{O}_{2}}$ using a thermostatted microelectrode assembly $\left(15 \pm 0.1^{\circ} \mathrm{C}\right.$, BMS 3, Radiometer, Copenhagen, Denmark). To avoid depleting the animals of coelomic fluid, samples used for blood gas analyses $(0.08-0.25 \mathrm{ml})$ were re-infused into the animals directly after measurements had been completed. The electrodes were calibrated using precision phosphate buffers (Radiometer, Copenhagen, Denmark) or humidified mixtures of $\mathrm{O}_{2}, \mathrm{CO}_{2}$ and $\mathrm{N}_{2}$ provided by gas-mixing pumps. The $\mathrm{CO}_{2}$ content $\left(\mathrm{C}_{\mathrm{CO}_{2}}\right)$ of plasma and water samples was analysed by means of a Capnicon III apparatus (Cameron Instruments, Port Aransas, TX, USA) or a Hach-Carle series 100 gas chromatograph, both calibrated with $\mathrm{NaHCO}_{3}$ standard solutions. Apparent bicarbonate levels were determined as $C_{\mathrm{CO}_{2}}-\alpha P_{\mathrm{CO}_{2}}$, where $\alpha$ is the solubility of $\mathrm{CO}_{2}$ in the respective compartment (calculated according to Heisler, 1986). Water bicarbonate levels were obtained from $\mathrm{pH}$ recordings, as described above.

Intracellular acid-base variables were analysed using the homogenate technique (Pörtner et al. 1990). In brief, tissue samples were ground under liquid nitrogen taking care that no condensation of $\mathrm{CO}_{2}$ or water occurred. Frozen tissue powder (100-200 mg) was added to $0.2 \mathrm{ml}$ of a solution containing KF $\left(160 \mathrm{mmoll}^{-1}\right)$ and nitrilotriacetic acid $\left(1 \mathrm{mmoll}^{-1}\right)$ in a $0.6 \mathrm{ml}$ Eppendorf tube (total volume of medium determined by mass). The Eppendorf tube was filled to the top with $\mathrm{KF} /$ nitrilotriacetic acid solution, closed and its contents mixed on a vortex mixer. After brief centrifugation, the supernatant was analysed for total $\mathrm{CO}_{2}$ content and $\mathrm{pH}$. Intracellular $\mathrm{C}_{\mathrm{CO}_{2}}$ and $P_{\mathrm{CO}_{2}}$ values were calculated from the total tissue $\mathrm{CO}_{2}$ content determinations taking into account the fractional values of water content and extracellular water in the tissue of this species determined at the same temperature (Pörtner, 1987) (see Pörtner et al. 1990 for the calculations involved). The remaining tissue powder was extracted in perchloric acid (Beis and Newsholme, 1975, modified according to Pette and Reichmann, 1982). Buffer value determinations in tissue homogenates followed the technique of Heisler and Piiper (1971) as modified by Pörtner (1990). Ammonium concentrations in water and plasma samples and the levels of phospho-L-arginine, L-arginine, inorganic phosphate and ATP in the muscle samples were analysed using established enzymatic procedures (see Bergmeyer et al. 1986; for the procedure used to determine inorganic phosphate concentration, see Pörtner, 1990). The octopine dehydrogenase used to assay octopine, phospho-L-arginine and arginine was prepared and purified for these determinations from the adductor muscles of Pecten maximus following the procedure described by Gäde and Carlsson (1984).

The levels of free ADP and AMP were calculated on the basis of the equilibrium of arginine kinase and myokinase. Equilibrium constants for both enzymes were corrected for experimental temperature and $\mathrm{pH}$-dependence with reference to the changing proton and magnesium binding of the adenylates and the proton turnover of the arginine kinase reaction (Pörtner, 1993; Pörtner et al. 1996).

Changes over time were tested for significance at the $5 \%$ level by using one-way or repeated-measures analysis of variance (ANOVA) and by performing the Bonferroni/Dunn post-hoc test or contrasts for group comparisons, the latter in repeated-measures experiments using SuperAnova, Abacus Concepts. Values are presented as means \pm S.E.M. throughout. Comparisons of data for normocapnic and hypercapnic animals under steady-state conditions and of energetic parameters in isolated tissue and whole animals were performed using Student's paired and unpaired $t$-tests.

\section{Results}

Sipunculus nudus has been shown previously to maintain 
more or less constant blood gas and acid-base variables, with constant rates of $\mathrm{H}^{+}$-equivalent ion exchange between the animals and the ambient water during extended control periods of up to 7 days (Pörtner et al. 1991). Therefore, the observed changes elicited by the experimental variations in water parameters can be expected to represent true experimental changes not caused by the length of the incubation period.

The time course of changes in the extracellular acid-base status was investigated in animals dwelling in a water recirculation system combined with the $\Delta$-bicarbonate analysis system (Fig. 1). Control extracellular acid-base parameters at time 0 before the onset of hypercapnia were $\mathrm{pH}=7.87 \pm 0.04, P_{\mathrm{CO}_{2}}=1.95 \pm 0.11 \mathrm{mmHg}(0.26 \pm 0.01 \mathrm{kPa})$ and $\left[\mathrm{HCO}_{3}{ }^{-}\right]=7.24 \pm 1.02 \mathrm{mmoll}^{-1}$; the rate of $\mathrm{H}^{+}$-equivalent ion exchange was $-0.06 \mathrm{mmol} \mathrm{h}^{-1} \mathrm{~kg}^{-1}$. Transmission of the

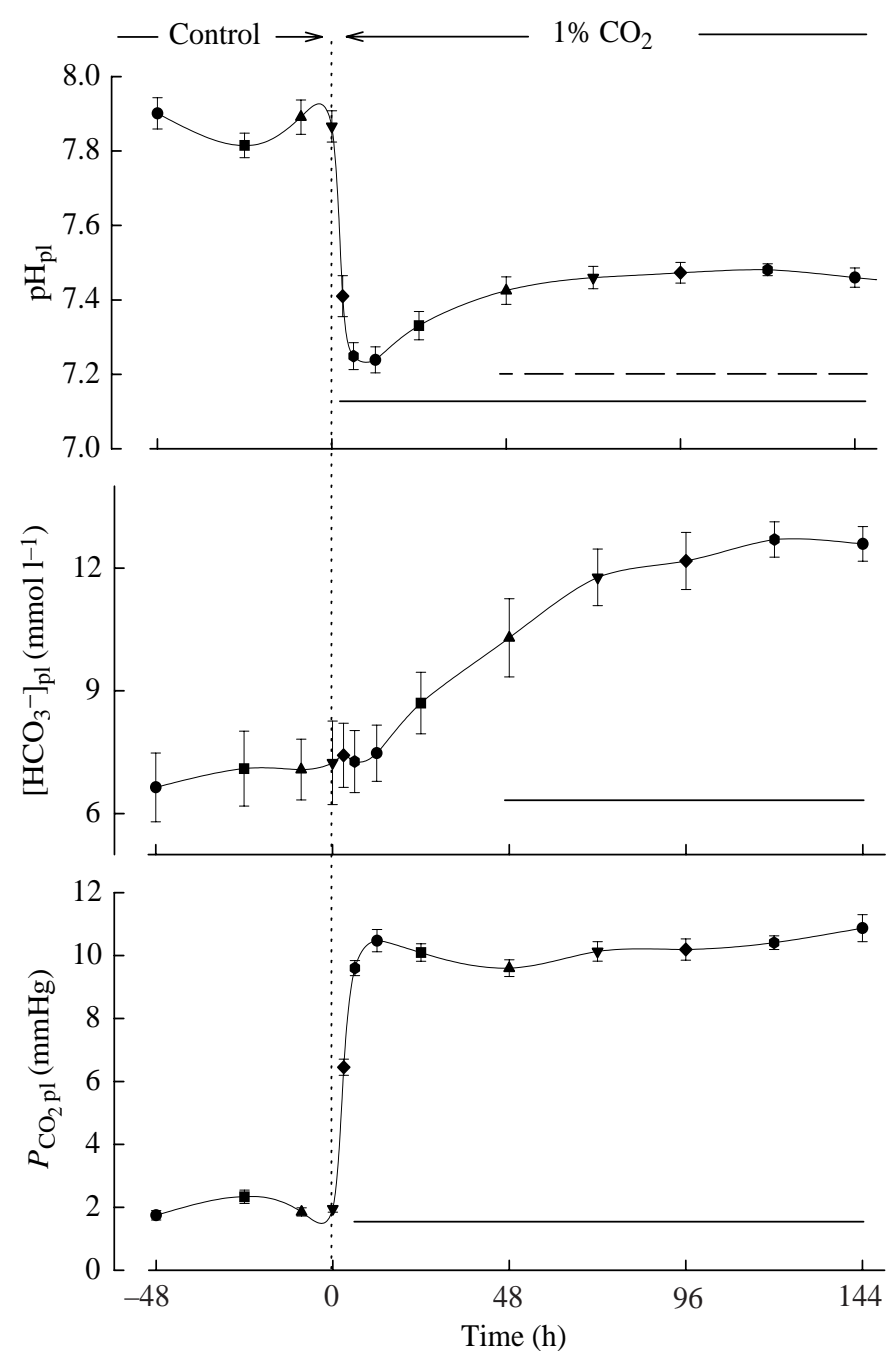

Fig. 1. Acid-base variables $\left(\mathrm{pH},\left[\mathrm{HCO}_{3}{ }^{-}\right], \mathrm{P}_{\mathrm{CO}_{2}}\right)$ in the coelomic plasma of Sipunculus nudus under control conditions and during the subsequent $144 \mathrm{~h}$ of hypercapnia $\left(1 \% \mathrm{CO}_{2}\right)$. Values are means \pm S.E.M., $N=4$. A horizontal line indicates the range of values significantly different from the control values; a broken line indicates the maintenance of a significant difference from $\mathrm{pH}$ values during short-term hypercapnia, i.e. at 6 and $12 \mathrm{~h}$ of hypercapnia). change in ambient $P_{\mathrm{CO}_{2}}$ to the extracellular space was complete after $6-12$ h (Fig. 1; see also Fig. 5). Seawater $\mathrm{pH}$ fell from 8.08 to 7.04 during saturation of the water with $1 \%$ $\mathrm{CO}_{2}$. Extracellular $\mathrm{pH}$ decreased to a minimum of $7.25 \pm 0.04$ after $6 \mathrm{~h}$, but later stabilized at approximately $\mathrm{pH} 7.45$ after $72 \mathrm{~h}$. Obviously, only partial extracellular compensation of the respiratory acidosis (by $37 \%$ ) had been achieved. During this time, coelomic plasma bicarbonate concentration rose to a new steady-state level of $12 \mathrm{mmoll}^{-1}$ when coelomic fluid $P_{\mathrm{CO}_{2}}$ stabilized at approximately $10 \mathrm{mmHg}$.

The time course of changes in intracellular acid-base status was investigated in animals dwelling in darkened aquaria containing a water volume of 51 (Fig. 2). With the onset of hypercapnia, intracellular $\mathrm{pH}$ fell to 7.24 over $3-6 \mathrm{~h}$ and remained constant for up to $12 \mathrm{~h}$. The intracellular acidosis was completely compensated within $48 \mathrm{~h}$ of hypercapnia. Intracellular $\mathrm{PCO}_{2}$ had reached steady-state values of $10.5-11 \mathrm{mmHg}$ after some initial oscillations between 3 and $12 \mathrm{~h}$. Intracellular bicarbonate concentration levelled off after
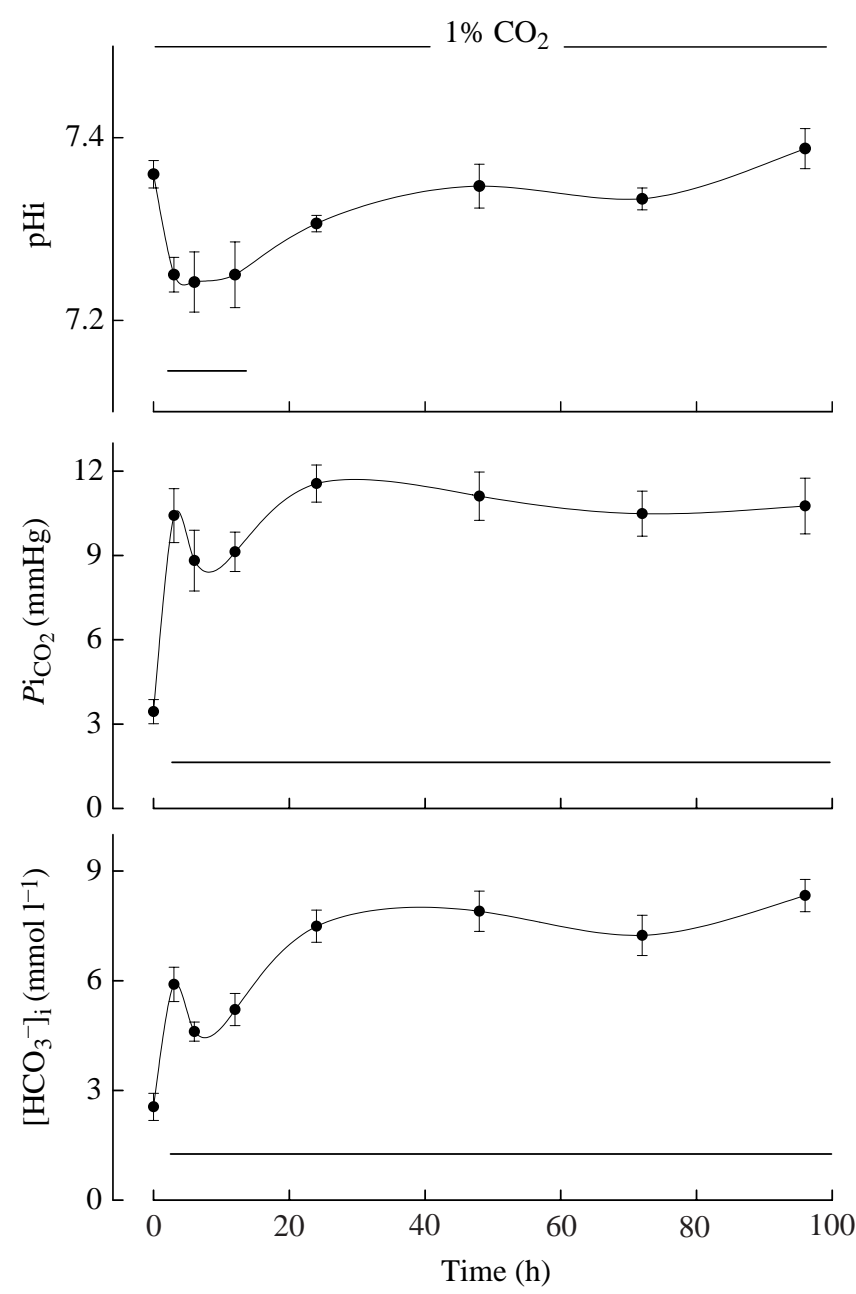

Fig. 2. Intracellular acid-base variables $\left(\mathrm{pH}, \mathrm{P}_{\mathrm{CO}_{2}},\left[\mathrm{HCO}_{3}{ }^{-}\right]\right)$in the body wall musculature of Sipunculus nudus under control conditions $(0 \mathrm{~h})$ and during the subsequent $96 \mathrm{~h}$ of hypercapnia $\left(1 \% \mathrm{CO}_{2}\right)$. Values are means \pm S.E.M., $N=5$ or 6 . A horizontal line indicates the range of values significantly different from control values. 
Table 1. Comparison of steady-state values of intra- and extracellular acid-base and gas variables in Sipunculus nudus before and during long-term hypercapnia

\begin{tabular}{|c|c|c|}
\hline & Normocapnia & Hypercapnia \\
\hline \multicolumn{3}{|l|}{ Aquarium } \\
\hline $\mathrm{pHe}$ & $8.02 \pm 0.03$ & $7.44 \pm 0.02 *(5)$ \\
\hline $\mathrm{pHi}$ & $7.36 \pm 0.01(5)$ & $7.33 \pm 0.01(5)$ \\
\hline$\Delta \mathrm{pH}$ & $0.65 \pm 0.03(5)$ & $0.12 \pm 0.01 *(5)$ \\
\hline$P \mathrm{e}_{\mathrm{CO}_{2}}(\mathrm{mmHg})$ & $1.6 \pm 0.2(5)$ & $8.0 \pm 0.4 *(5)$ \\
\hline $\mathrm{Pi}_{\mathrm{CO}_{2}}(\mathrm{mmHg})$ & $3.4 \pm 0.4(5)$ & $10.5 \pm 0.8 *(5)$ \\
\hline$\Delta P_{\mathrm{CO}_{2}}(\mathrm{mmHg})$ & $1.8 \pm 0.4(5)$ & $2.5 \pm 0.7(5)$ \\
\hline$\left[\mathrm{HCO}_{3}{ }^{-}\right]_{\mathrm{e}}\left(\mathrm{mmol}^{-1}\right)$ & $7.2 \pm 0.2(5)$ & $10.6 \pm 0.3 *(5)$ \\
\hline$\left[\mathrm{HCO}_{3}^{-}\right]_{\mathrm{i}}\left(\mathrm{mmoll}^{-1}\right)$ & $2.6 \pm 0.4(5)$ & $7.2 \pm 0.5 *(5)$ \\
\hline$\Delta\left[\mathrm{HCO}_{3}^{-}\right]\left(\mathrm{mmoll}^{-1}\right)$ & $4.6 \pm 0.3(5)$ & $3.7 \pm 0.7(5)$ \\
\hline \multicolumn{3}{|l|}{ Water recirculation system } \\
\hline $\mathrm{PeCO}_{2}$ & $1.94 \pm 0.08(7)$ & $10.6 \pm 0.4 *(6)$ \\
\hline$P \mathrm{wCO}_{2}$ & $0.57 \pm 0.03(6)$ & $7.8 \pm 0.1 *(4)$ \\
\hline$\Delta P_{\mathrm{CO}_{2}}$ & 1.37 & 2.81 \\
\hline $\mathrm{PeO}_{2}$ & $25.8 \pm 3.8(7)$ & $14.2 \pm 2.1 *(6)$ \\
\hline $\mathrm{PWO}_{2}$ & $110.0 \pm 3.6(4)$ & $111.0 \pm 2.7(4)$ \\
\hline$\Delta P_{\mathrm{O}_{2}}$ & 84.2 & 96.8 \\
\hline
\end{tabular}

Values are means \pm S.E.M. $(N)$.

* Significantly different from the normocapnic value, $P<0.05$.

Experimental hypercapnia was induced by treatment with $1 \% \mathrm{CO}_{2}$ for $120 \mathrm{~h}$

$24 \mathrm{~h}$, and values remained more or less contant between 7.2 and $8.3 \mathrm{mmoll}^{-1}$ thereafter. In order to compare the data collected in low-volume recirculation systems and with that from relatively large aquaria, extracellular data were recorded for steady-state normocapnia and hypercapnia in some animals killed for pHi analysis (Table 1).

Fig. 3 shows the effect of hypercapnia on coelomic $P_{\mathrm{O}_{2}}$ (data collected as for Fig. 1). An initial sharp drop from control levels of $29.6 \pm 5.9 \mathrm{mmHg}(3.95 \pm 0.79 \mathrm{kPa})$ at time $0 \mathrm{~h}$ to $17.1 \pm 2.3 \mathrm{mmHg}(2.28 \pm 0.31 \mathrm{kPa})$ was followed by a transient rise and slow fluctuations around a mean value of approximately $17 \mathrm{mmHg}$. Plasma ammonium levels also showed oscillations but remained more or less constant under control and hypercapnic conditions. Table 1 compares steadystate water and intra- and extracellular acid-base parameters and gas partial pressures under control conditions and during long-term hypercapnia. Only those values collected in the same experimental arrangement are compared. The differences between intra- and extracellular $P_{\mathrm{CO}_{2}}$ as well as between extracellular and water $P_{\mathrm{CO}_{2}}$ increased during hypercapnia, as did the $P_{\mathrm{O}_{2}}$ difference between the extracellular fluid and the water.

The observed net release of base equivalents under control conditions was similar to the pattern described previously (Pörtner et al. 1991; Fig. 4). Hypercapnia reversed the flux of

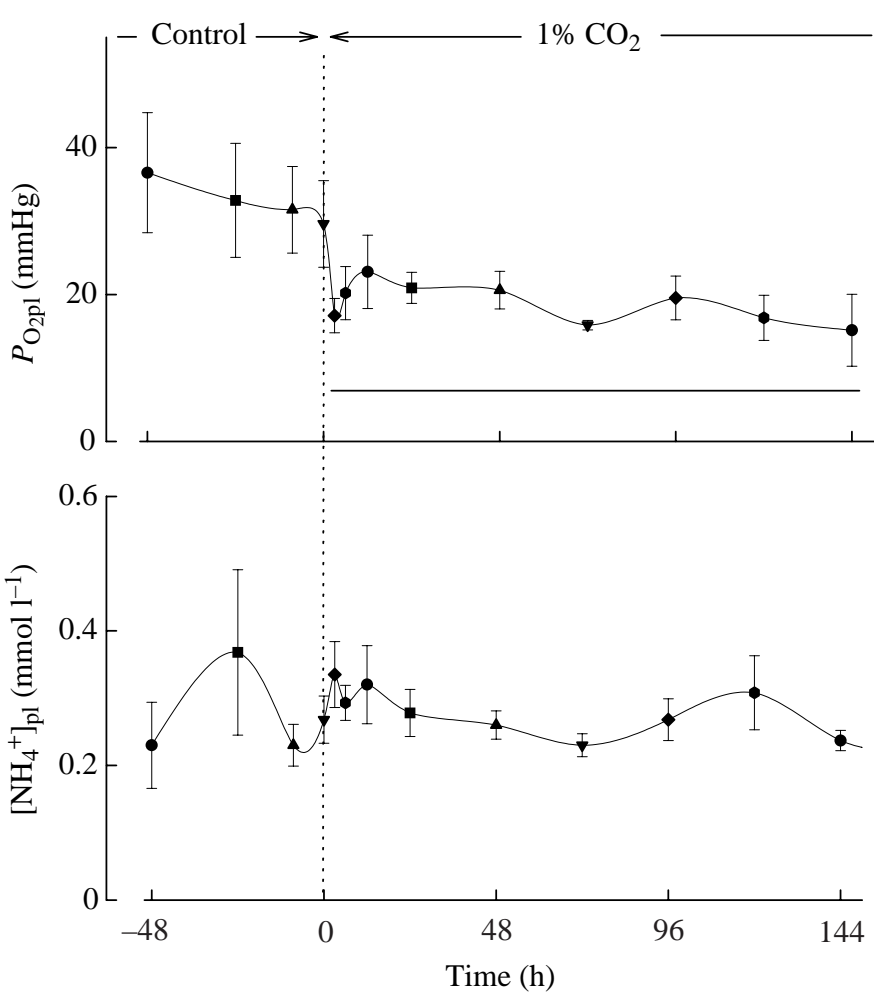

Fig. 3. $P_{\mathrm{O}_{2}}$ and ammonium levels in the coelomic plasma of Sipunculus nudus under control conditions and during the subsequent $144 \mathrm{~h}$ of hypercapnia $\left(1 \% \mathrm{CO}_{2}\right)$. Values are means \pm S.E.M., $N=4$. A horizontal line indicates the range of values significantly different from control values.

acid-base equivalents, resulting in a net uptake of bicarbonateequivalent ions. This transient net bicarbonate uptake resulted in a transient reduction in the rate of water alkalization. When intra- and extracellular acid-base parameters had reached new steady-state values, the direction of the net proton flux returned to the original direction of base release, although at a reduced rate reflected by the increase in the rate of ammonium excretion.

This finding was confirmed during analysis of the return to normocapnia in a separate experiment (Fig. 5A-D). Changes seen during long-term hypercapnia were very similar to those depicted in Fig. 4. The return to normocapnia led to a transient accumulation of bicarbonate in the coelomic plasma linked to an overshoot in extracellular pH. $P_{\mathrm{CO}_{2}}$ fell to control normocapnic values within $12 \mathrm{~h}$. Plasma $\mathrm{pH}$ returned to control values within 72-96h. Coelomic bicarbonate concentration approached, but did not reach, normocapnic levels during this period (Fig. 5A-C). Finally, the return to normocapnia caused an increase in the net release of base equivalents (Fig. 5D). Taking into account the reduced rate of net base release during hypercapnia, the animals lost exactly the amount of base that they had accumulated during hypercapnia.

The transient intracellular acidosis observed during the first day of hypercapnia was followed by a delayed decrease in the level of phospho-L-arginine, indicated by a reduced 


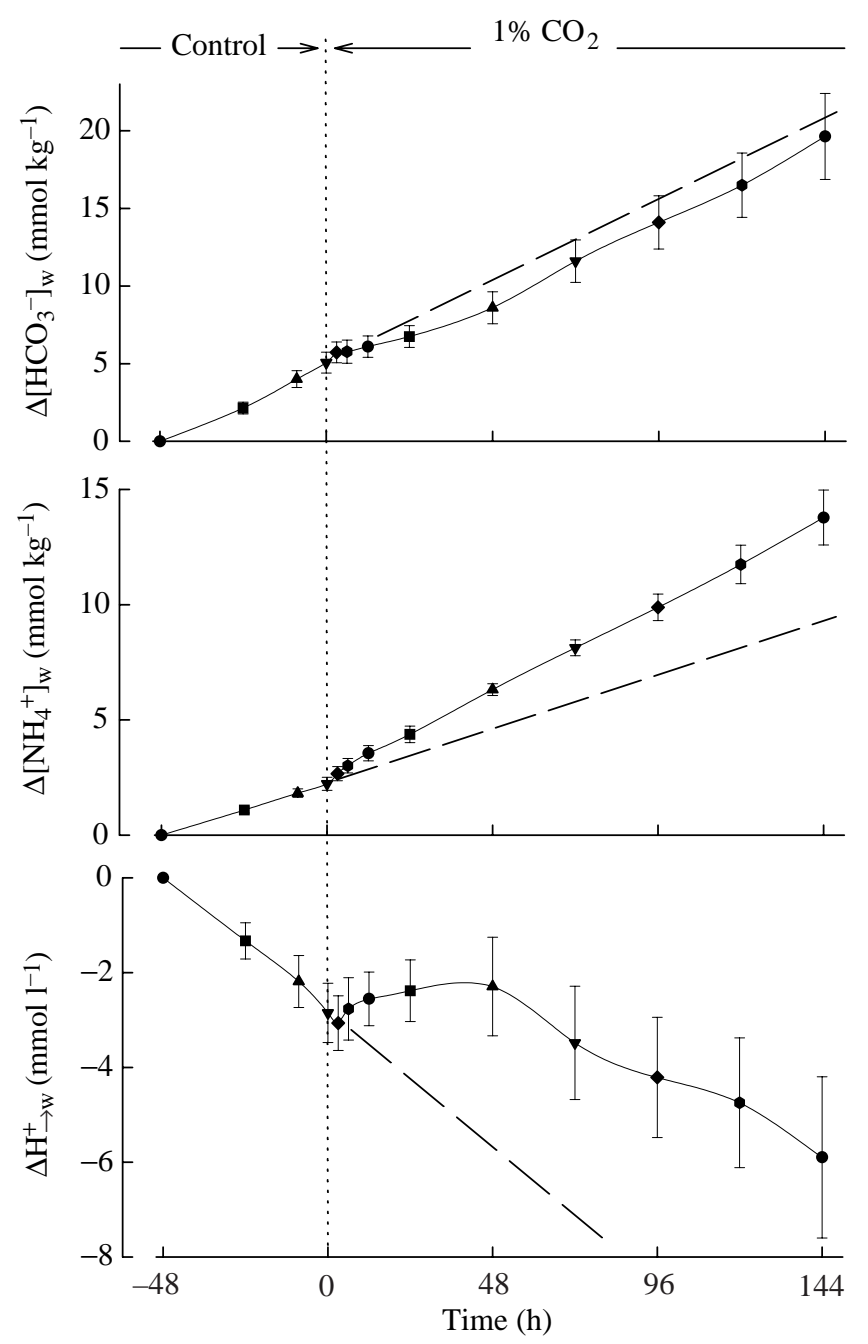

Fig. 4. $\mathrm{H}^{+}$-equivalent ion transfer $\left(\Delta \mathrm{H}^{+} \rightarrow \mathrm{w}\right)$ between the animals (extracellular data in Fig. 1) and the ambient water, calculated from changes in ammonium and bicarbonate levels in the water. Control rates are extrapolated (dashed line) for the experimental period. Values are means \pm S.E.M, $N=4$. Note the increase in the rate of ammonium excretion during hypercapnia (cf. Fig. 8).

ratio [phospho-L-arginine]/[phospho-L-arginine + L-arginine] (Fig. 6). The return to control $\mathrm{pH}$ during long-term exposure to hypercapnia resulted in a return of the phospho-L-arginine level to the control level. Fluctuations in phosphagen levels were reflected by a significant transient rise in inorganic phosphate concentrations. Fig. 7 shows that ATP levels remained unaffected and that a slight accumulation of free ADP and AMP occurred during the period when phospho-Larginine levels fell. Levels of free ADP and AMP were insignificantly different from control levels but were significantly different from the values reached during longterm hypercapnia. The value of the Gibb's free energy change of ATP hydrolysis initially fell significantly during hypercapnic acidosis. The decrease was mostly dependent upon the rise in inorganic phosphate level and was reversed when the phosphate level returned to the control value during long-term hypercapnia. Minimum levels of free ADP, free

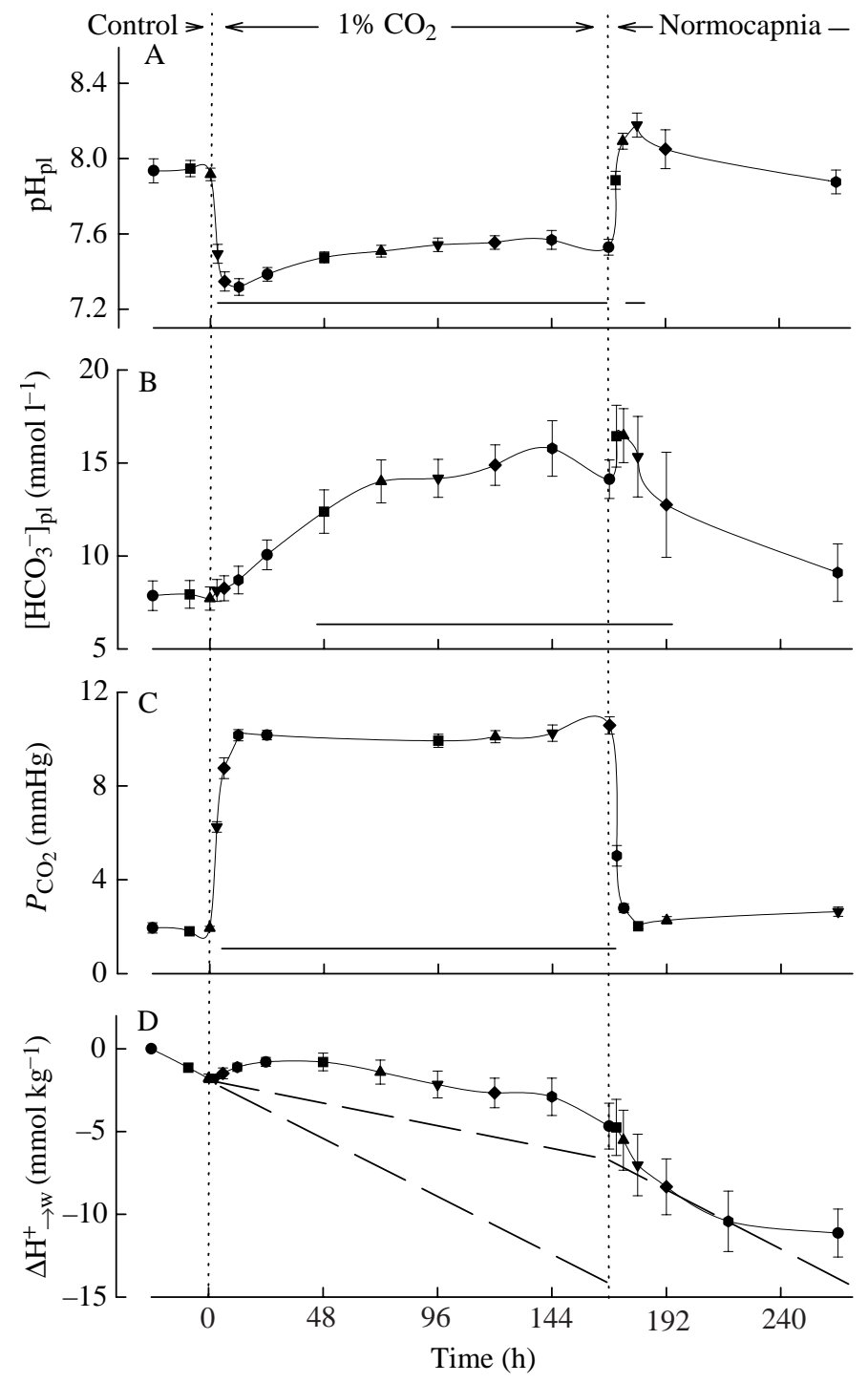

Fig. 5. (A-C) Acid-base variables (pH, $\left.\left[\mathrm{HCO}_{3}^{-}\right], P_{\mathrm{CO}_{2}}\right)$ in the coelomic plasma of Sipunculus nudus under control conditions, during $168 \mathrm{~h}$ of hypercapnia $\left(1 \% \mathrm{CO}_{2}\right)$ and during the subsequent return to control conditions. Note the overshoot in extracellular $\mathrm{pH}$ and bicarbonate levels during the return to normocapnia. A horizontal line indicates the range of values significantly different from control values. (D) $\mathrm{H}^{+}$-equivalent ion transfer $\left(\Delta \mathrm{H}^{+} \rightarrow \mathrm{w}\right)$ between the animals and the ambient water calculated from changes in water ammonium and bicarbonate levels. The control rate and the hypercapnic rate are extrapolated (dashed lines) for the subsequent experimental period. Values are mean \pm S.E.M., $N=4$.

AMP and inorganic phosphate, and maximum values of the ratio [phospho-L-arginine]/[phospho-L-arginine + L-arginine] and the ATP free energy change were seen after $96 \mathrm{~h}$ of hypercapnia.

The time courses of intra- and extracellular acid-base changes can only be compared with caution owing to different experimental conditions. Quantitative analysis of extracellular acid-base changes demonstrates that the extracellular acidosis exceeded the extent of acidification expected from $\mathrm{CO}_{2}$ 
accumulation. For this analysis, tissue non-bicarbonate buffer values were determined as $16.0 \pm 1.3 \mathrm{mmol} \mathrm{kg}^{-1} \mathrm{pHunit}^{-1}$ (mean \pm S.E.M., $N=18$ ), and a coelomic fluid buffer value of $4.6 \mathrm{mmol} \mathrm{kg} \mathrm{kH}^{-1}$ was adopted from Pörtner et al. (1984). After $3 \mathrm{~h}$, a non-respiratory acidification of $1.9 \mathrm{mmol} \mathrm{H}^{+} \mathrm{l}^{-1}$ in excess of respiratory acidification was observed in the coelomic plasma. At this time, the intracellular acidosis was almost maximal, but with a base excess of $0.7 \mathrm{mmol}^{-1}$ instead of a deficit. The maximum extent of extracellular nonrespiratory acidification (resulting in a base deficit of $2.9 \mathrm{mmoll}^{-1}$ after $6 \mathrm{~h}$ of hypercapnia) coincided with the maximum drop in extracellular $\mathrm{pH}$. At the same time, intracellular $\mathrm{pH}$ had reached its minimum value, representing a slight base excess of $0.2 \mathrm{mmoll}^{-1}$ cell water, which

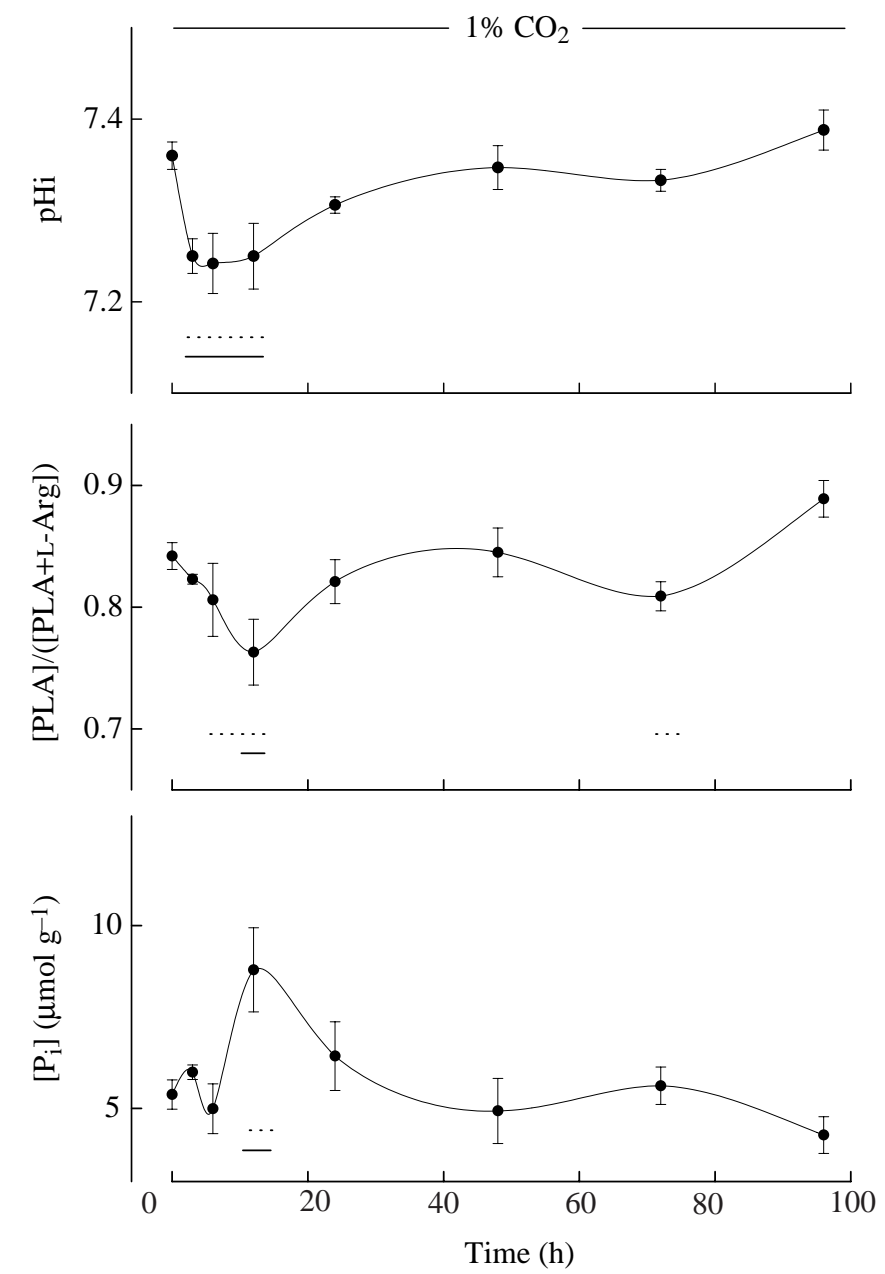

Fig. 6. Changes in pHi, in the ratio [phospho-L-arginine]/[phospho-Larginine + L-arginine] and in the inorganic phosphate $\left(\mathrm{P}_{\mathrm{i}}\right)$ concentration in the body wall musculature of Sipunculus nudus under control conditions ( $\mathrm{pHi}=7.36 \pm 0.02$, [phospho-L-arginine]/[phosphoL-arginine + L-arginine $]=0.84 \pm 0.01 ;\left[\mathrm{P}_{\mathrm{i}}\right]=5.4 \pm 0.4 \mu \mathrm{mol} \mathrm{g}^{-1}$ wet mass $)$ and during the subsequent $96 \mathrm{~h}$ of hypercapnia $\left(1 \% \mathrm{CO}_{2}\right)$. Values are means \pm S.E.M., $N=5$ or 6 . A horizontal line indicates the range of values significantly different from control values; a broken line indicates that values are significantly different from that measured after long-term hypercapnia, i.e. at $96 \mathrm{~h}$ of hypercapnia. PLA, phospho-L-arginine; L-Arg; L-arginine. increased to $0.9 \mathrm{mmoll}^{-1}$ after $12 \mathrm{~h}$. Under steady-state conditions (after approximately $48 \mathrm{~h}$ of hypercapnia), nonrespiratory base equivalents accumulated in the intra- and extracellular body fluids amounted to $1.77 \mathrm{mmol} \mathrm{kg}^{-1}$ $\left(\Delta \mathrm{HCO}_{3}{ }^{-}\right.$non-resp. $=\left[0.58 \times\left(0.73 \mathrm{mmol}^{-1}\right.\right.$ coelomic plasma $)+$ $0.19 \times\left(4.93 \mathrm{mmol}^{-1}\right.$ cell water of the musculature $\left.)\right] /$ $0.77=1.77 \mathrm{mmol} \mathrm{kg}^{-1}$ ) (for details of the equation and body fluid fractions, see Pörtner, 1987). Changes in $85 \%$ of the animal's body mass were considered in this analysis, which compares well with the net uptake of base equivalents of

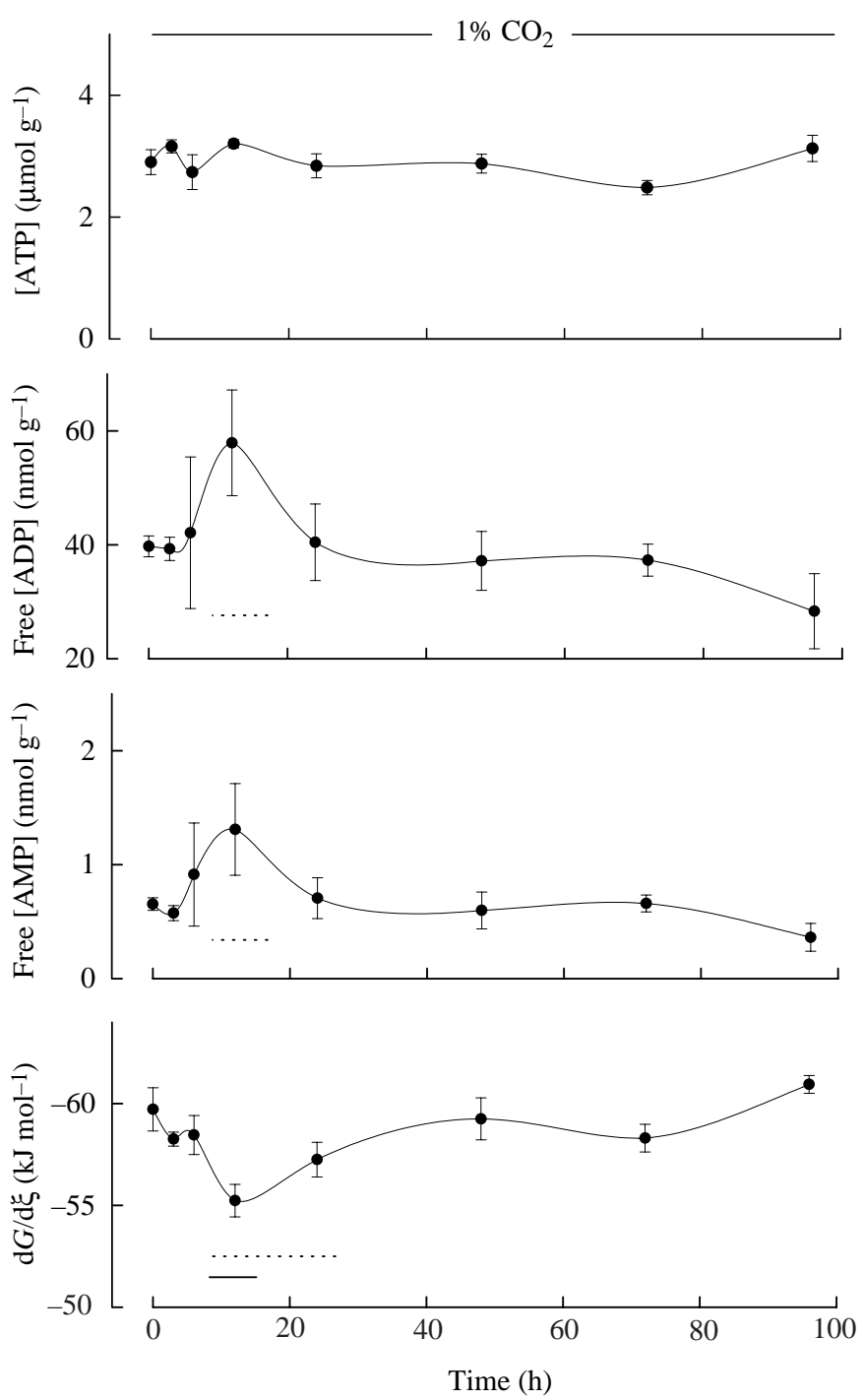

Fig. 7. ATP levels, the concentrations of unbound ADP and AMP and the levels of ATP free energy, in the body wall musculature of Sipunculus nudus under control conditions ([ATP $]=2.90 \pm 0.21 \mu \mathrm{mol}$ $\mathrm{g}^{-1}$ wet mass; $[\mathrm{ADP}]_{\text {free }}=40 \pm 2 \mathrm{nmol} \mathrm{g}^{-1}$ wet mass; $[\mathrm{AMP}]_{\text {free }}=$ $0.65 \pm 0.06 \mathrm{nmol} \mathrm{g}^{-1}$ wet mass; ATP free energy, $\mathrm{d} G / \mathrm{d} \xi=$ $-59.7 \pm 1.1 \mathrm{~kJ} \mathrm{~mol}^{-1}$ and during the subsequent $96 \mathrm{~h}$ of hypercapnia $\left(1 \% \mathrm{CO}_{2}\right)$. Values are means \pm S.E.M., $N=5$ or 6 . A horizontal line indicates the range of values significantly different from control values; a broken line indicates that values are significantly different from that measured after long-term hypercapnia, i.e. at $96 \mathrm{~h}$ of hypercapnia. 


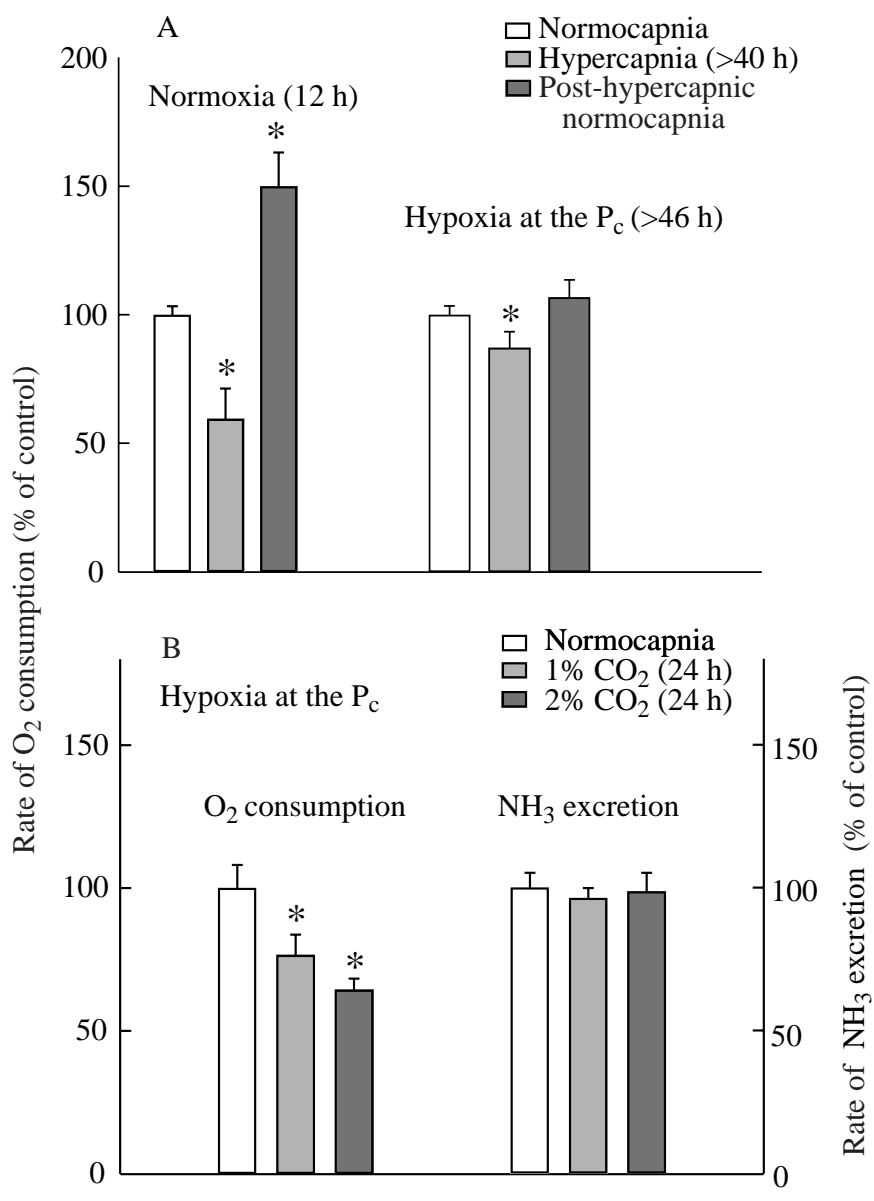

Fig. 8. (A) Rates of oxygen consumption during normocapnia, after subsequent exposure to hypercapnia $\left(1 \% \mathrm{CO}_{2}\right.$ for $\left.>40 \mathrm{~h}\right)$ and after the return to normocapnia. This protocol ensured that acid-base parameters had reached new steady-state values under hypercapnia. Note the increase in the rate of oxygen consumption during the first hours of post-hypercapnic normocapnia. (B) Rates of oxygen consumption and ammonia excretion under 1 and $2 \% \mathrm{CO}_{2}$ in air. The data measured in a closed system confirm the reduction in the $\mathrm{O} / \mathrm{N}$ ratio derived from the drop in metabolic rate and from the increase in the rate of ammonium excretion shown in Fig. 4 (open system). An asterisk indicates a significant difference from the control values. Values are means + S.E.M., $N=5-6 . P_{\mathrm{c}}$, critical $P_{\mathrm{O}_{2}}$.

$1.8 \mathrm{mmol} \mathrm{kg}^{-1}$ body mass derived from the changes in water parameters of the $\Delta$-bicarbonate system.

Closed-system respirometry revealed that hypercapnic exposure caused metabolic depression in Sipunculus nudus (Fig. 8). The decrease in the rate of oxygen consumption was maintained after steady-state conditions had been attained with respect to the levels of intra- and extracellular acid-base parameters. A decrease in the rate of oxygen consumption was observed under both normoxia and hypoxia (the level of $P_{\mathrm{O}_{2}}$ chosen was slightly above the critical $P_{\mathrm{O}_{2}}$, defined as the ambient oxygen level below which anaerobiosis sets in; Pörtner and Grieshaber, 1993; Fig. 8A). The return to normocapnia was correlated with a significant rise in the rate of oxygen consumption above control values after $12 \mathrm{~h}$. This overshoot was reversed after normocapnic recovery for at least
$46 \mathrm{~h}$. The reduction in the rate of oxygen consumption was related to the level of ambient hypercapnia. Hypercapnia of $2 \%$ was almost twice as effective as exposure to $1 \% \mathrm{CO}_{2}$ (Fig. $8 \mathrm{~B})$. The increase in the rate of ammonia/ammonium excretion in the (open) water recirculation system could not be confirmed during closed-system respirometry. However, the rate of ammonia excretion remained constant and independent of the level of ambient $\mathrm{CO}_{2}$, thereby confirming that the $\mathrm{O} / \mathrm{N}$ ratio (8.4 \pm 0.6 under control conditions), reflecting the contribution of protein/amino acid metabolism to the overall metabolic rate, fell in animals exposed to hypercapnia by $19 \pm 9 \%\left(1 \% \mathrm{CO}_{2}\right)$ or by $36 \pm 2 \%\left(2 \% \mathrm{CO}_{2}\right)$ (mean \pm S.E.M., $\left.N=5\right)$.

The ventilatory frequency of animals dwelling in sand reflected the changes in metabolic rate and fell significantly

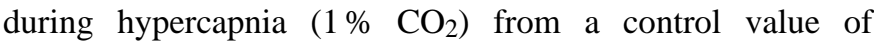
$2.27 \pm 0.16$ to $1.78 \pm 0.24 \mathrm{~min}^{-1}$ (mean \pm S.E.M., $N=4$ ); control values were exceeded between 9 and $12 \mathrm{~h}$ of recovery at a level of $2.83 \pm 0.53 \mathrm{~min}^{-1}(N=3)$. Adenosine infusions caused a small and insignificant drop in ventilatory frequency from $2.12 \pm 0.24$ to $1.97 \pm 0.08 \mathrm{~min}^{-1}$ during the period $1.5-3 \mathrm{~h}$ after infusion, when a maximum drop in the rate of oxygen consumption had been observed in previous experiments (Reipschläger et al., 1997).

\section{Discussion \\ Acid-base regulation}

Like the findings of Lindinger et al. (1984) in Mytilus edulis, acid-base regulation during hypercapnia in Sipunculus nudus occurs as an accumulation of bicarbonate in body fluid compartments to compensate for the respiratory acidosis. In $S$. nudus, all of the bicarbonate originates from ion exchange with the ambient water, whereas in M. edulis the dissolution of the shell is largely responsible for this process. Starting at lower bicarbonate levels in the intra- than in the extracellular space, total base accumulation occurred to a similar extent in both compartments in $S$. nudus. The relative capacity of $\mathrm{pH}$ regulatory mechanisms appears to be larger in the tissues, since compensation of the intracellular acidosis was faster and occurred initially at the expense of an increase in the extracellular acidosis. A base deficit transiently developing in the coelomic plasma indicates that transfer mechanisms between the coelomic fluid and water are slower than the net base exchange rate between the body wall musculature and coelomic fluid. Finally, the intracellular acidosis was more or less completely compensated during hypercapnia, while accumulation of bicarbonate in the extracellular space was not sufficient for full recovery of $\mathrm{pHe}$.

The final steady-state value of extracellular $\mathrm{pH}$ is a direct function of the acid-base characteristics of the medium. In support of this conclusion, changes in water bicarbonate levels under normocapnia were seen to modulate extracellular bicarbonate levels (Table 2). Accordingly, an increasing degree of extracellular compensation is expected in hypercapnic sea water at higher bicarbonate levels. Heisler (1984, 1986) suggested that a maximum extracellular 
Table 2. Coelomic plasma and water bicarbonate levels in Sipunculus nudus before and during experimental hypercapnia or after titration of water bicarbonate levels under normocapnia in the water recirculation system

\begin{tabular}{lcccc}
\hline & \multicolumn{4}{c}{$\left[\mathrm{HCO}_{3}{ }^{-}\right]\left(\mathrm{mmol} \mathrm{l}^{-1}\right)$} \\
\cline { 2 - 5 } Experiment & Water & $\begin{array}{c}\text { Plasma } \\
\text { normocapnia }\end{array}$ & $\begin{array}{c}\text { Plasma } \\
\text { hypercapnia }\end{array}$ & $\Delta\left[\mathrm{HCO}_{3}{ }^{-}\right]_{\mathrm{e}-\mathrm{w}}$ \\
\hline I & 3.4 & $6.8 \pm 0.3$ & - & 3.4 \\
& 2.9 & $5.7 \pm 0.3$ & - & 2.8 \\
& 1.0 & $5.2 \pm 0.3$ & - & 4.2 \\
& 0.6 & $3.9 \pm 0.3^{*}$ & - & 3.3 \\
II & 2.8 & $7.1 \pm 0.7$ & - & 4.3 \\
& 3.3 & - & $12.7 \pm 0.4^{*}$ & 9.4
\end{tabular}

Data are from two experiments, experiment I and II.

*Significant difference from control values (normocapnia at 2.8 or $2.9 \mathrm{mmoll}^{-1} \mathrm{HCO}_{3}{ }^{-}$in experiments I and II, respectively).

Note the maintenance of the bicarbonate gradient $\left(\Delta\left[\mathrm{HCO}_{3}^{-}\right]_{\mathrm{e}-\mathrm{w}}\right)$ during changes in $\left[\mathrm{HCO}_{3}{ }^{-}\right]_{\mathrm{W}}$ and normocapnia and the increase in the bicarbonate concentration difference during hypercapnia.

Experimental hypercapnia was induced by treatment with $1 \% \mathrm{CO}_{2}$ for $120 \mathrm{~h}$

Values are means \pm S.E.M., $N=4$.

bicarbonate concentration may determine the extent to which extracellular respiratory acidification can be compensated in fish. This maximum concentration may be related to a maximum concentration difference or ratio between the extracellular space and the ambient water beyond which passive loss is equivalent to the rate of uptake. Water-breathers in general maintain lower extracellular bicarbonate levels than air-breathers and, for this reason, concentration gradients are smaller and extracellular compensation is more complete. Under $1 \% \mathrm{CO}_{2}$, extracellular compensation is usually almost complete in marine fish (e.g. Toews et al. 1983; Claiborne and Evans, 1992), less complete in crabs (e.g. Cameron and Iwama, 1987) and even less complete in the sipunculid worm, although partial compensation of the extracellular acidosis required the concentration difference between plasma and water bicarbonate to rise from 4.3 to approximately $10 \mathrm{mmoll}^{-1}$ (Table 2). Compensation was also incomplete in M. edulis, despite the use of shell carbonate for buffering (Lindinger et al. 1984). Some animals (e.g. channel catfish, blue crab and possibly M. edulis) are able to shift the bicarbonate threshold to higher levels according to the degree of hypercapnia (Lindinger et al. 1984; Cameron and Iwama; 1989, Heisler, 1993). The range of concentrations used in the present experiments does not allow us to identify a maximum extracellular level in $S$. nudus. Further research is required to compare vertebrate and invertebrate capacities of acid-base regulation.

If an elastic bicarbonate threshold exists for the extracellular compartment, it may also exist intracellularly. Intracellular $\mathrm{pH}$ depends upon extracellular $\mathrm{pH}$ in the isolated byssus retractor muscle of Mytilus edulis (Zange et al. 1990), in isolated rat heart (Sugden and Fuller, 1991) and also in the isolated body wall musculature of Sipunculus nudus (Reipschläger and Pörtner, 1996). The maintenance of intracellular $\mathrm{pH}$ under normocapnic control conditions was associated with a $\mathrm{HCO}_{3}{ }^{-}$ concentration difference of approximately $4 \mathrm{mmol} \mathrm{l}^{-1}$ between the intra- and extracellular spaces. Although, at present, we cannot evaluate why and how such a gradient is maintained, it is intriguing that similar quantities of bicarbonate were accumulated intra- and extracellularly and, in consequence, the same concentration difference was seen during long-term hypercapnia (Table 1). Adopting the principles elaborated above for the extracellular compartment, intracellular compensation appears to be easier since baseline $\mathrm{pH}$ and, thus, bicarbonate levels are low, leaving more scope for an increase in bicarbonate concentration. The Henderson-Hasselbalch equation predicts that less bicarbonate is required to be accumulated intracellularly to re-establish a low control pHi, whereas the higher set point of extracellular $\mathrm{pH}$ requires more bicarbonate to be accumulated per $\mathrm{pH}$ unit of compensation than in the intracellular space.

The correlated time courses of intra- and extracellular compensation strongly suggest that intracellular compensation was supported by the increase in extracellular $\mathrm{pH}$ and bicarbonate levels, even though extracellular compensation remained incomplete. Intracellular $\mathrm{pH}$ remained at its minimum value and was more or less constant as long as extracellular $\mathrm{pH}$ and bicarbonate levels were minimal. $\mathrm{pHi}$ started to rise only when extracellular parameters also increased. In isolated body wall musculature, steady-state $\mathrm{pHi}$ values were reduced when hypercapnic tissues were exposed to an extracellular $\mathrm{pH}$ close to the lowest values observed in vivo (see Fig. 1). Control values of intracellular $\mathrm{pH}$ in hypercapnic muscle preparations were re-established only at extracellular $\mathrm{pH}$ values comparable to that attained after compensation in vivo (Fig. 1; Reipschläger and Pörtner, 1996). As a corollary, only with partial compensation of the extracellular acidosis during hypercapnia and the associated accumulation of bicarbonate are intact animals able to adjust pHi to pre-hypercapnic values. Accordingly, intracellular compensation is limited by the maximum extracellular bicarbonate level, which is a function of the level of hypercapnia. These interrelationships emphasize the importance of an integrated control of extracellular and intracellular acid-base status under control conditions and during environmental stress.

The present data support the more general hypothesis that, rather than maintaining absolute levels of $\mathrm{pH}$, actual values depend upon steady-state ionic equilibria between the intraand extracellular compartments and the ambient media. Only in media reflecting a 'normal' environment in terms of ion composition and $\mathrm{pH}$ are set points of acid-base parameters typical of control conditions observed.

Compensation of the intracellular acidosis was not observed in M. edulis during hypercapnia, possibly owing to the limited duration of the hypercapnic exposure $(24 \mathrm{~h})$. However, a 
metabolic acidosis developed in M. edulis during hypercapnia, suggesting metabolic depression so severe that ventilation may have become insufficient and that anaerobic metabolism may have been utilized for energy production (Lindinger et al. 1984). In contrast, ambient $P_{\mathrm{O}_{2}}$ was above the critical $P_{\mathrm{O}_{2}}$ in the present study (see Pörtner et al. 1985), and coelomic fluid $P_{\mathrm{O}_{2}}$ was maintained at a high level during hypercapnia in $S$. nudus, suggesting that the animals were completely aerobic.

\section{Metabolic depression and the mode of metabolism}

Although control values of $\mathrm{pHi}$ regulation were successfully re-established during long-term hypercapnia, elevated $\mathrm{CO}_{2}$ levels caused a decrease in the rate of oxygen consumption under both normoxia and at levels of hypoxia slightly above the critical $P_{\mathrm{O}_{2}}$ (Fig. 8A), indicating that the depressant effect of $\mathrm{CO}_{2}$ is independent of ambient oxygen level. S. nudus is an oxyconformer, probably with a variable contribution to oxygen consumption from an alternative oxidase (Pörtner and Grieshaber, 1993). Nonetheless, metabolic depression was independent of the actual rate of oxygen consumption, which varied with ambient $P_{\mathrm{O}_{2}}$. The hypercapnia-induced fall in metabolic rate in Sipunculus nudus occurred even at normal pHi. Therefore, as verified in a companion study (Reipschläger and Pörtner, 1996), a contribution of intracellular $\mathrm{pH}$ to metabolic depression is most unlikely in this species. However, extracellular $\mathrm{pH}$ in vivo remained reduced under these conditions, and a separate study conducted using isolated body wall musculature has demonstrated that a decrease in extracellular $\mathrm{pH}$ rather than intracellular $\mathrm{pH}$ caused metabolic depression in Sipunculus nudus (Reipschläger and Pörtner, 1996).

The data obtained in the water recirculation system show an increase in the rate of ammonium accumulation in the water during hypercapnia, with constant ammonium levels in the coelomic plasma (Figs 3,4). Under the conditions of an open system, this could be caused either by an increased trapping of ammonia in the ambient water at low $\mathrm{pH}$ or by an increase in the rate of ammonia production and excretion, reflecting a drop in the $\mathrm{O} / \mathrm{N}$ ratio and, thus, a shift to the catabolism of protein or amino acids. Reinvestigation of ammonia release in a closed system could not confirm the rise in ammonium production during hypercapnia (Fig. 8B). This may be due to ammonium accumulation in the plasma, owing to the development of a non-equilibrium condition in the closed chamber, or to seasonal differences (collection of animals at different times of the year, see Materials and methods). However, the $\mathrm{O} / \mathrm{N}$ ratio drops during hypercapnia. A value of 8.4 during normocapnia indicates that metabolism in Sipunculus relies largely on amino acids as fuel, and this reliance is even greater during hypercapnia with even lower $\mathrm{O} / \mathrm{N}$ ratios. The mechanism causing the increase in amino acid catabolism is unclear; however, if metabolic depression does include a reduction in the rate of protein synthesis, as described for hypoxic animals (Hofmann and Hand, 1990; Land et al. 1993), a diminished recruitment of amino acids for protein synthesis could be associated with their increased use as metabolic substrates under conditions when the rate of amino acid release from protein degradation is more or less unchanged.

Amino acid degradation leads to the production of metabolic bicarbonate and ammonium (Atkinson and Camien, 1982). When water-breathers release ammonia, the remaining $\mathrm{H}^{+}$ neutralizes the accumulating bicarbonate (see Pörtner, 1989). If ammonium is released by ion exchange instead, an increase in metabolic bicarbonate production associated with increased amino acid degradation might support the rise in intra- and extracellular bicarbonate levels and not only reduce the total workload for ion-exchange mechanisms but also accelerate the establishment of new acid-base equilibria. The detailed mechanisms regulating the metabolic contribution to acid-base regulation require further investigation. Nonetheless, net $\mathrm{H}^{+}$equivalent ion exchange, which is equivalent to a net release of base under normocapnic control conditions, shifts to a reduced rate of base release during hypercapnia. Thereby, it reflects an increased net production of protons in metabolism, as expected from the proton balance of overall amino acid catabolism, which leads to ammonium formation in excess of bicarbonate formation and, consequently, net acid excretion (see Pörtner, 1989, 1995).

\section{Metabolic changes and tissue energetics}

The decrease in overall metabolic rate was related to a fall in plasma $P_{\mathrm{O}_{2}}$ (Fig. 3) and a rise in $P_{\mathrm{CO}_{2}}$, resulting in an increased difference between the animals and their environment and, at least for $\mathrm{CO}_{2}$, also between the intra- and extracellular spaces (Table 1). These changes suggest that a depression of gas exchange has occurred, a conclusion also supported by the finding of a decrease in ventilatory frequency during hypercapnia. A reduction in ventilatory activity would suggest that a central nervous mechanism contributes to metabolic depression. In a companion study (Reipschläger $e t$ al. 1997), we have demonstrated that adenosine accumulates in the nervous tissue of animals during hypercapnia and contributes to metabolic depression. Adenosine infusion in animals dwelling in sand caused a slight but insignificant drop in ventilatory frequency.

During the transition to long-term hypercapnia, oscillations in plasma $\mathrm{O}_{2}$ and tissue $\mathrm{CO}_{2}$ levels were similar, with an initial sharp drop in plasma $P_{\mathrm{O}_{2}}$ and an associated rise in tissue $P_{\mathrm{CO}_{2}}$ (Figs 2,3). A subsequent rise in plasma $P_{\mathrm{O}_{2}}$ and drop in tissue $\mathrm{P}_{\mathrm{CO}_{2}}$ compensated for these initial changes. Although oxygen consumption data are not available for this period, the rationale outlined above suggests that ventilation and metabolic rate rose again after an initial drop; however, this compensatory effect was only transient and was followed by the documented longterm metabolic depression. Recordings of ventilation frequency reflected the transient rise in metabolic rate after $12 \mathrm{~h}$ of hypercapnia, but did not reach significance levels (results not shown).

The fluctuations in the levels of high-energy phosphates support these conclusions and also suggest that an immediate drop in metabolic rate occurred with the onset of hypercapnia, followed by a compensatory rise before energy turnover fell 
again during the transition to steady-state hypercapnic depression. This hypothesis is supported by the time courses of changes in pHi and phospho-L-arginine levels and by the discrepancy observed between them. Phosphagens such as phospho-L-arginine (PLA) are rapidly available energy reserves which will buffer any drastic change in energy demand even when catabolism remains fully aerobic. Protons are involved in the transphosphorylation of the phosphagen and, therefore, influence the equilibrium of arginine kinase (simplified):

$$
\begin{gathered}
\mathrm{PLA}^{-}+\mathrm{MgADP}^{-}+\mathrm{H}^{+} \leftrightharpoons \mathrm{MgATP}^{2-}+\mathrm{L}_{-} \text {arginine } \\
\mathrm{MgATP}^{2-} \leftrightharpoons \mathrm{MgADP}^{-}+x \mathrm{P}_{\mathrm{i}}{ }^{2-}+(1-x) \mathrm{P}_{\mathrm{i}}^{-}+x \mathrm{H}^{+} .
\end{gathered}
$$

An acidosis, therefore, could be expected to cause a drop in phospho-L-arginine levels associated with a decrease in the ratio [phospho-L-arginine]/[phospho-L-arginine + L-arginine]. Finally, transphosphorylation and subsequent utilization of MgATP would lead to a net release of inorganic phosphate.

However, phosphagen levels did not follow the sharp drop in $\mathrm{pHi}$ and decreased significantly only after $12 \mathrm{~h}$, although intracellular $\mathrm{pH}$ had already reached close to minimum values after 3-6h. Moreover, the delayed decrease in phosphagen levels was associated with a delayed rise in free ADP and AMP levels which, in combination with the rise in phosphate levels, led to a significant drop in the Gibb's free energy of ATP hydrolysis (Figs 6, 7). The effect of $\mathrm{pH}$ itself on the latter parameter remained small and almost negligible under these circumstances (see Pörtner, 1993). In accordance with the picture arising from the changes in gas partial pressure gradients, we suggest that the delayed drop in phospho-Larginine level and the rise in free ADP and AMP levels are caused by a transient increase in metabolic rate after an initial drop during early hypercapnia. These initial oscillations in high-energy phosphate levels were followed by long-term metabolic depression, which allowed phospho-L-arginine levels to rise again. Similarly, a transient drop in phospho-Larginine levels followed by a compensatory rise was also seen during the transient overshoot in oxygen consumption caused by a temperature rise in the Antarctic limpet Nacella concinna (S. Zielinski, L. Peck and H. O. Pörtner, unpublished results).

In conclusion, the immediate fall in energy turnover during early hypercapnia may have prevented the acidosis from causing a parallel drop in phospho-L-arginine levels. In support of this hypothesis, phosphagen levels also remained constant in isolated hypercapnic body wall musculature despite the development of an intracellular acidosis (Reipschläger and Pörtner, 1996). These observations are in accordance with the conclusions by Meyer et al. (1991), who also suggested that the development of an acidosis need not necessarily cause phosphagen depletion.

The observation that the decrease in intracellular $\mathrm{pH}$ during hypercapnia did not cause a depletion of phospho-L-arginine indicates that intracellular $\mathrm{pH}$ and phosphagen metabolism remain uncoupled when metabolic rate is low. The levels of the phosphagen and the Gibb's free energy change of ATP hydrolysis both fell only after an initial delay, probably at higher metabolic rates, associated with the respective accumulation of free ADP and inorganic phosphate. In support of this conclusion, the Gibb's free energy change of ATP hydrolysis was significantly higher in isolated body wall musculature $\left(-66 \pm 2 \mathrm{~kJ} \mathrm{~mol}^{-1}\right.$, [phospho-L-arginine]/[phosphoL-arginine $+\mathrm{L}$-arginine $]=0.96 \pm 0.01 ;\left[\mathrm{P}_{\mathrm{i}}\right]=0.8 \pm 0.5 \mu \mathrm{mol} \mathrm{g}^{-1}$ wet mass, [free ADP $]=6 \pm 2 \mathrm{nmol} \mathrm{g}^{-1}$ wet mass at minimal metabolic rate; data from Reipschläger and Pörtner, 1996) than in the body wall of intact animals $\left(-60 \pm 1 \mathrm{~kJ} \mathrm{~mol}^{-1}\right.$, [phosphoL-arginine $] /[$ phospho-L-arginine + L-arginine $]=0.84 \pm 0.01$; $\left[\mathrm{P}_{\mathrm{i}}\right]=5.4 \pm 0.4 \mu \mathrm{mol} \mathrm{g}^{-1}$ wet mass, [free ADP] $=40 \pm 1 \mathrm{nmol} \mathrm{g}^{-1}$ wet mass; this study), very probably because of a higher metabolic rate in vivo. All of these values were obtained at similar intracellular $\mathrm{pH}$ values under conditions which can be termed aerobic control conditions. The comparison emphasizes that aerobic metabolic rate and the energy status of a tissue are inversely coupled with large factorial rises in the level of free ADP at higher metabolic rates. This may hold true even for interspecies comparisons considering, for example, the high values of $100 \mathrm{nmol}_{\text {free }} \mathrm{ADP} \mathrm{g}^{-1}$ wet mass in resting squid mantle musculature (Finke et al. 1996), which exhibits high rates of oxygen consumption under control conditions.

\section{Conclusions}

Acid-base regulation in $S$. nudus during hypercapnia occurred as an accumulation of bicarbonate to a similar extent in the extra- and intracellular spaces. The amount of bicarbonate accumulated was sufficient to compensate for hypercapnia-induced intracellular acidification, but left the extracellular space partially uncompensated. Although extracellular compensation was incomplete, it provided a preconditioning for the re-establishment of control intracellular $\mathrm{pH}$ values. Accordingly, steady-state extracellular $\mathrm{pH}$ and intra- and extracellular $P_{\mathrm{CO}_{2}}$ and bicarbonate levels shifted in association with a decreased steady-state rate of metabolism in $S$. nudus in vivo. A reduction in ventilation frequency caused a rise in gas partial pressure gradients between the intra- and extracellular body compartments and between the extracellular space and the ambient water.

The compensation of the intracellular acidosis during longterm hypercapnia eliminates intracellular $\mathrm{pH}$ as an important factor in long-term metabolic down-regulation. Companion studies have demonstrated that metabolic depression during steady-state hypercapnia is mediated by a decrease in extracellular $\mathrm{pH}$ effective at the cellular level (Reipschläger and Pörtner, 1996) and by a depression of central nervous activity mediated by adenosine accumulation (Reipschläger $e t$ al. 1997). The overshoot in metabolic rate seen during recovery from hypercapnic exposure resembles the payment of an oxygen debt after anoxic exposure; however, the mechanism remains unexplained. Hypercapnic depression caused metabolism to shift to an increased proportion of protein and amino acid catabolism, as indicated by the drop in $\mathrm{O} / \mathrm{N}$ ratios and the increased release of proton equivalents seen as a net change in the steady-state transepithelial transfer of acid-base 
equivalent ions. The mechanisms eliciting this shift also require further investigation.

Fluctuations in gas partial pressures, levels of high-energy phosphates and ventilatory frequency suggest that the period of transition to hypercapnia was characterized by an initial drop in metabolic rate and ventilation frequency, followed by a transient compensatory rise before the initiation of long-term metabolic depression. The mechanism behind the oscillatory transition to long-term hypercapnia remains obscure. Different time courses of changes in $\mathrm{pHi}$ and phospho-L-arginine levels indicate that intracellular $\mathrm{pH}$ and phosphagen metabolism remain uncoupled when metabolic rate is low. A small rise in metabolic rate is accompanied by a large factorial rise in free ADP levels, which appears to be the key factor modulating phosphagen levels even under fully aerobic conditions.

This work was supported by grants from the Deutsche Forschungsgemeinschaft (Po 278). H.O.P. acknowledges receipt of a Max-Planck fellowship during a stay at the MPI für experimentelle Medizin. We thank T. Hirse for help with the data evaluation. Alfred-Wegener-Institute publication no. 1336.

\section{References}

Atkinson, D. E. And Camien, M. N. (1982). The role of urea synthesis in the removal of metabolic bicarbonate and the regulation of blood pH. Curr. Topics cell. Regul. 21, 261-302.

BARNHART, M. C. (1989). Respiratory acidosis and metabolic depression in dormant invertebrates. In Living in the Cold (ed. A. Malan and B. Canguilhem), pp. 315-401. Colloque INSERM/John Libbey Eurotext Ltd.

BARnhart, M. C. AND McMahon, B. R. (1988). Depression of aerobic metabolism and intracellular $\mathrm{pH}$ by hypercapnia in land snails Otala lactea. J. exp. Biol. 138, 289-299.

BeIs, I. AND Newsholme, E. A. (1975). The contents of adenine nucleotides, phosphagens and some glycolytic intermediates in resting muscles from vertebrates and invertebrates. Biochem. J. 152, 23-32.

Bergmeyer, H. U., BERGMEYER, J. AND GRAßL, M. (1983-1986). (eds) Methods of Enzymatic Analysis. Weinheim: Verlag Chemie.

Brooks, S. P. J. AND STOREY, K. B. (1989). Influence of hormones, second messengers and $\mathrm{pH}$ on the expression of metabolic responses to anoxia in a marine whelk. J. exp. Biol. 145, 31-43.

Busa, W. B. AND Crowe, J. H. (1983). Intracellular pH regulates transitions between dormancy and development of brine shrimp (Artemia salina) embryos. Science 221, 366-368.

Cameron, J. N. And Iwama, G. K. (1987). Compensation of progressive hypercapnia in channel catfish and blue crabs. J. exp. Biol. 133, 183-197.

Cameron, J. N. And Iwama, G. K. (1989). Compromises between ionic regulation and acid-base regulation in aquatic animals. Can. J. Zool. 67, 3078-3084.

Claiborne, J. B. and Evans, D. E. (1992). Acid-base balance and ion transfers in the spiny dogfish (Squalus acanthias) during hypercapnia: A role for ammonia excretion. J. exp. Zool. 261, 9-17.

Finke, E., Pörtner, H. O., Lee, P. G. And Webber, D. M. (1996). Squid (Lolliguncula brevis) life in shallow waters: oxygen limitation of metabolism and swimming performance. J. exp. Biol. 199, 911-921.

Gäde, G. AND CARlsson, K.-H. (1984). Purification and characterization of octopine dehydrogenase from the marine nemertean Cerebratulus lacteus (Anopla: Heteronemerta): comparison with scallop octopine dehydrogenase. Mar. Biol. 79, 39-45.

HAND, S. C. AND GNAIGER, E. (1988). Anaerobic dormancy quantified in Artemia embryos: a calorimetric test of the control mechanisms. Science 239, 1425-1427.

Hardewig, J., Addink, A. D. F., Grieshaber, M. K., Pörtner, H. O. AND VAN DEN THILlaRT, G. (1991). Metabolic rates at different oxygen levels determined by direct and indirect calorimetry in the oxyconformer Sipumculus nudus. J. exp. Biol. 157, 143-160.

HEISLER, N. (1984). Acid-base regulation in fishes. In Fish Physiology, vol. XA (ed. W. S. Hoar and D. J. Randall), pp. 315-401. New York: Academic Press.

HEISLER, N. (1986). Buffering and transmembrane ion transfer processes. In Acid-Base Regulation in Animals (ed. N. Heisler), pp. 3-47. Amsterdam: Elsevier Biomedical Press.

HeISLER, N. (1989). Parameters and methods in acid-base physiology. In Techniques in Comparative Respiratory Physiology (ed. C. R. Bridges and P. J. Butler), pp. 305-332. Cambridge: Cambridge University Press.

Heisler, N. (1993). Acid-base regulation. In The Physiology of Fishes (ed. D. H. Evans), pp. 343-377. Boca Raton FL: CRC Press Inc.

HeISLER, N. AND PIIPER, J. (1971). The buffer value of rat diaphragm muscle tissue determined by $\mathrm{PCO}_{2}$ equilibration of homogenates. Respir. Physiol. 12, 169-178.

Hofmann, G. E. And Hand, S. C. (1990). Arrest of cytochrome c oxidase synthesis coordinated with catabolic arrest in dormant Artemia embryos. Am. J. Physiol. 258, R1184-R1991.

JACKSON, D. C., WASSER, J. S. AND SILVER, R. B. (1988). Effects of induced hypercapnia on anaerobic metabolic rate of anoxic musk turtles. Am. J. Physiol. 254, R944-R948.

Land, S. C., Buck, L. T. AND HochachKa, P. W. (1993). Response of protein synthesis to anoxia and recovery in anoxia-tolerant hepatocytes. Am. J. Physiol. 265, R41-R48.

Lindinger, M. I., Lauren, D. J. And McDonald, D. G. (1984). Acid-base balance in the sea mussel, Mytilus edulis. III. Effects of environmental hypercapnia on intra- and extracellular acid-base balance. Mar. Biol. Lett. 5, 371-381.

Meyer, R. A., Adams, G. R., Fisher, M. J., Dillon, P. F., Krisand, J. M., Brown, T. R. And Kushmerick, M. J. (1991). Effect of decreased $\mathrm{pH}$ on force and phosphocreatine in mammalian skeletal muscle. Can. J. Physiol. Pharmac. 69, 305-310.

Pette, D. And Reichmann, H. (1982). A method for quantitative extraction of enzymes and metabolites from tissue samples in the milligram range. J. Histochem. Cytochem. 30, 401-402.

PöRTNER, H. O. (1987). Anaerobic metabolism and changes in acid-base status: quantitative interrelationships and $\mathrm{pH}$ regulation in the marine worm Sipunculus nudus. J. exp. Biol. 131, 89-105.

PörTNER, H. O. (1989). The importance of metabolism in acid-base regulation and acid-base methodology. Can. J. Zool. 67, 3005-3017.

PöRTNER, H. O. (1990). Determination of intracellular buffer values after metabolic inhibition by fluoride and nitrilotriacetic acid. Respir. Physiol. 81, 275-288.

PÖRTNER, H. O. (1993). Multicompartmental analyses of acid-base and metabolic homeostasis during anaerobiosis: invertebrate and 
lower vertebrate examples. In Surviving Hypoxia: Mechanisms of Control and Adaptation (ed. P. W. Hochachka, P. L. Lutz, T. Sick, M. Rosenthal and G. van den Thillart), pp. 139-156. Boca Raton FL: CRC Press Inc.

PÖRTNER, H. O. (1995). pH homeostasis in terrestrial vertebrates: a comparison of traditional and new concepts. Curr. Adv. comp. env. Physiol. 22, 51-62.

Pörtner, H. O., Andersen, N. A. And Heisler, N. (1991). Protonequivalent ion transfer in Sipunculus nudus as a function of ambient oxygen tension: relationships with energy metabolism. J. exp. Biol. 156, 21-39.

Pörtner, H. O., Boutilier, R. G., TAng, Y. And Toews, D. P. (1990). Determination of intracellular $\mathrm{pH}$ and $\mathrm{PCO}_{2}$ after metabolic inhibition by fluoride and nitrilotriacetic acid. Respir. Physiol. 81, 255-274.

Pörtner, H. O., Finke, E. ANd Lee, P. G. (1996). Metabolic and energy correlates of intracellular $\mathrm{pH}$ in progressive fatigue of squid (Lolliguncula brevis) mantle muscle. Am. J. Physiol. 271, R1403-R1414.

PÖRTNER, H. O. AND GRIESHABER, M. K. (1993). Characteristics of the critical $P_{\mathrm{O}_{2}}(\mathrm{~s})$ : gas exchange, metabolic rate and the mode of energy production. In The Vertebrate Gas Transport Cascade: Adaptations to Environment and Mode of Life (ed. J. E. P. W. Bicudo), pp. 330-357. Boca Raton FL: CRC Press Inc.

Pörtner, H. O., Grieshaber, M. K. AND Heisler, N. (1984). Anaerobiosis and acid-base status in marine invertebrates: effect of environmental hypoxia on extracellular and intracellular $\mathrm{pH}$ in Sipunculus nudus L. J. comp. Physiol. B 155, 13-20.

Pörtner, H. O., Heisler, N. ANd Grieshaber, M. K. (1985). Oxygen consumption and mode of energy production in the intertidal worm Sipunculus nudus L.: definition and characterization of the critical $\mathrm{P}_{\mathrm{O}_{2}}$ for an oxyconformer. Respir. Physiol. 59, 361-377.
ReEs, B. B. AND HAND, S. C. (1990). Heat dissipation, gas exchange and acid-base status in the land snail Oreohelix during short-term estivation. J. exp. Biol. 152, 77-92.

ReEs, B. B. AND Hand, S. C. (1991). Regulation of glycolysis in the land snail Oreohelix during estivation and artificial hypercapnia. $J$. comp. Physiol. B 161, 237-246.

Reipschläger, A., Nilsson, G. E. And Pörtner, H. O. (1997). Adenosine is a mediator of metabolic depression in the marine worm Sipunculus nudus. Am. J. Physiol. 272, R350-R356.

REIPSCHLÄGER, A. AND PÖRTNER, H. O. (1996). Metabolic depression during environmental stress: the role of extra- versus intracellular pH in Sipunculus nudus. J. exp. Biol. 199, 1801-1807.

Scholnick, D. A., SNYder, G. K. ANd Spell, A. R. (1994). Acid-base status of a pulmonate land snail (Helix aspersa) and a prosobranch amphibious snail (Pomacea bridgesi) during dormancy. J. exp. Zool. 268, 293-298.

Silver, R. B. AND JACKSON, D. C. (1985). Ventilatory and acid-base responses to long-term hypercapnia in the freshwater turtle Chrysemys picta bellii. J. exp. Biol. 114, 661-672.

Sugden, P. H. AND FulLer, S. J. (1991). Correlations between cardiac protein synthesis rates, intracellular $\mathrm{pH}$ and the concentrations of creatine metabolites. Biochem. J. 273, 339-346.

Toews, D. P., Holeton, G. F. AND Heisler, N. (1983). Regulation of the acid-base status during environmental hypercapnia in the marine teleost fish Conger conger. J. exp. Biol. 107, 9-20.

Zange, J., Grieshaber, M. K. And Jans, A. W. H. (1990). The regulation of intracellular $\mathrm{pH}$ estimated by ${ }^{31} \mathrm{P}-\mathrm{NMR}$ spectroscopy in the anterior byssus retractor muscle of Mytilus edulis L. J. exp. Biol. 150, 95-109.

ZIELINSKI, S. AND PöRTNER, H.O. (1996). Energy metabolism and ATP free-energy change of the intertidal worm Sipunculus nudus below a critical temperature. J. comp. Physiol. 166B, 492-500. 